\title{
PENDIDIKAN KARAKTER BERBASAIS SASTRA SEJARAH DALAM PUISI "AKU TIDAK BISA MENULIS PUISI LAGI" KARYA SUBAGIO SASTROWARDOYO
}

\author{
Sugeng Supriyono ${ }^{l a}$, Nugraheni Eko Wardani ${ }^{b}$, \& Kundharu Saddhono ${ }^{c}$ \\ ${ }^{a}$ Mahasiswa Prodi Pendidikan Bahasa Indonesia \\ Pascasarjana FKIP Universitas Sebelas Maret Surakarta \\ ${ }^{b, c}$ Dosen Pendidikan Bahasa Indonesia Pascasarjana FKIP Univesitas Sebelas Maret, Indonesia \\ Jalan Ir. Sutami 36 A, Surakarta, 57126
}

\begin{abstract}
ABSTRAK
Puisi sebagai karya sastra merupakan wujud budaya manusia yang sarat akan nilai-nilai kehidupan, maka sangat relevan dalam pembentukan karakter. Tujuan penelitian ini untuk mendeskripsikan nilai-nilai karakter dalam puisi Aku Tidak Bisa Menulis Puisi Lagi karya Subagio Sastrowardoyo. Bentuk penelitian ini adalah kualitatif deskriptif dengan analisis contens. Data penelitian ini berupa dokumen teks puisi karya Subagio Sastrowardoyo dengan judul Aku Tak Bisa Menulis Puisi Lagi. Teknik analisis data menggunakan teknik simak dan catat. Pendekatan yang digunakan dalam penelitian ini adalah pendekatan stilistika. Dari penelitian yang telah dilakukan ditemukan hasil bahwa, terdapat lima nilai karakter dalam puisi Aku Tidak Bisa Menulis Puisi Lagi karya Subagio Sastrowardoyo.
\end{abstract}

Kata Kunci: puisi, karakter, stilistika

Poetry as a literature work is a manifestation of human culture that full of value of life, so it's very relevant for character building. The aim of this research is to describe character value of poetry "Aku Tidak Bisa Menulis Puisi Lagi" from Subagio Sastrowardoyo. This research is qualitative research applying the descriptive and using content analysis. Data of this research is Subagio Sastrowardoyo's poetry "Aku Tak Bisa Menulis Puisi Lagi”. Technique of data analysis are referenced technique and recorded technique. Approach technique that used is sylistic approach. The results of this research are found five characters in this poetry.

Keywords: poetry, character, stylistic

\section{PENDAHULUAN}

Penguatan pendidikan karakter (moral education) atau pendidikan karakter (character education) dalam konteks sekarang merupakan kebutuhan yang sangat mendesak untuk mengatasi krisis moral yang melanda di negara kita. Krisis tersebut diantaranya disebabkan oleh derasnya arus globalisasi yang berdampak lahirnya budaya massa. Budaya massa telah mengubah perilaku bangsa kita dari budaya pancasila kearah budaya liberalis, kapitalis. Gaya hidup hedonistis, sikap individualistis, adalah potret budaya massa yang menggerus identitas bangsa kita sebagai bangsa yang berbudaya dan beradab.
Krisis moral dikalangan remaja merebak dalam beragam bentuk. Fenomena maraknya tawuran antar pelajar, pesta miras, pergaulan bebas, hingga pembunuhan di kalangan remaja cukuplah sebagai indikasi terjadinya dekadensi moral generasi penerus bangsa kita. Praktik jual beli kunci jawaban soal ujian nasional dijenjang Sekolah Menengah Pertama dan Menengah Atas kiranya semakin menambah deretan panjang krisis moral dan mental yang telah mengikis seluruh sendi cara hidup siswa yang jauh dari akhlak mulia.

Untuk menyikapi permasalahan

di atas tentunya dibutuhkan kepedulian dan kerja nyata dari seluruh pihak, baik orang tua, lingkungan masyarakat, lembaga pendidikan maupun para steak holder yang

\footnotetext{
${ }^{1}$ Penulis Koresponden

E-mail address: sugengsupriyonoo@gmail.com doi: http://dx.doi.org/10.25157/ja.v4i2.835
} 
terkait. Kemauan politik pemerintah secara serius dalam hal ini tentunya menjadi kunci pembuka mengatasi permasalahan tersebut. Berkenaan dengan ini, pemerintah melalui kementrian pendidikan nasional telah mencanangkan penguatan pendidikan karakter diseluruh jenjang pendidikan dengan ditetapkannya undang-undang tentang sistem pendidikan nasioanal.

Pendidikan adalah usaha sadar dan terencana untuk mewujudkan suasana belajar dan proses pembelajaran agar peserta didik secara aktif mengembangkan potensi dirinya untuk memiliki kekuatan spiritual keagamaan, pengendalian diri, kepribadian, kecerdasan, akhlak mulia, serta keterampilan yang diperlukan dirinya, masyarakat, bangsa, dan negara (UU RI No. 20, 2003: Pasal 1 ayat 1). Undang -undang itu mengisyaratkan, bahwa tujuan pendidikan nasional adalah membetuk peserta didik berperilaku baik dan berilmu pengetahuan. Dengan kata lain hakikat pendidikan bertujuan membetuk keselarasan antara kecerdasan spititual, intelektual, dan sosial peserta didik.

Pendidikan nasional mempuyai visi terwujudnya sistem pendidikan sebagi pranata sosial yang kuat dan berwibawa untuk memberdayakan semua warga negara Indonesia berkembang menjadi manusia yang berkualitas sehingga mampu dan proaktif menjawab tantangan zaman yang selalu beubah. Tujuan pendidikan memuat gambaran yang baik, luhur, pantas, benar, dan indah untuk kehidupan.

Karakter, dipandang sebagai penentu bahwa seseorang sebagai pribadi (character is personality evaluated). Karakter terbentuk dari tiga macam bagian yang saling berkaitan yakni pengetahuan moral, perasaan moral, dan perilaku moral (Lickona, 2012: 72). Dengan demikian dapat dimaknai bahwa karakter adalah tabiat yang telah melekat dalam diri manusia.

Pendidikan karakter diartikan sebagai upaya penanaman kecerdasan dalam berfikir, penghayatan dalam bentuk sikap, dan pengalaman dalam bentuk perilaku yang sesuai dengan nilai-nilai luhur yang menjadi jati dirinya, diwujudkan dalam interaksi dengan Tuhannya, diri sendiri, masyarakat, dan lingkungannya (Zubaidi, 2011: 17). Pendidikan karakter adalah pendidikan budi pekerti plus, yang melibatkan aspek pengetahuan (cognitive), perasaan (felling), dan tindakan (action) (Wibowo, 2012: 33). Pendidikan karakter juga diartikan sebagai sebuah upaya mendidik anak- anak agar dapat mengambil keputusan dengan bijak dan mempraktikannya dalam kehidupan sehari-hari, sehingga mereka dapat memberikan kontribusi yang positip kepada lingkungan (Megawangi dalam Kesuma dkk, 2012: 5). Koesuma mengungkapkan bahwa pendidikan karakter adalah usaha yang dilakukan secara individu dan sosial dalam menciptakan lingkungan yang kondusif bagi kebebasan pertumbuhan individu itu sendiri (2010: 194).

Mencermati berbagai pendapat di atas, maka implementasi pendidikan karakter haruslah diintegrasikan dalam proses pembelajaran disemua mata pelajaran, dan diseluruh jenjang pendidikan wajib dilakukan. Dalam konteks kelembagaan di sekolah, pendidikan budi pekerti atau karakter sebisa mungkin berpijak pada warisan kebudayan yang menjadi nilai-nilai luhur dalam pembetukan manusia yang bermartabat dan berkeadaban (Ilahi, 2014: 83).

Puisi sebagai salah satu karya sastra merupakan wujud warisan budaya bangsa dalam bentuk teks tertulis. Puisi tidak lahir dari kekosongan, puisi lahir dari proses perenungan yang mendalam. Puisi sebagai karya sastra dipandang sebagai dokumen sosial yang di dalamnya merupakan refleksi situasi pada masa sastra itu diciptakan dan sastra juga wujud cermin situasi sosial penulisnya. Satsra juga dipandang sebagai manifestasi peristiwa sejarah dan keadaan sosial budaya (Endraswara, 2012: 81).

Sebagai manifestasi peristiwa sejarah dan sosial budaya, puisi yang merupakan salah satu genre sastra sangatlah tepat dijadikan sebagai media pendidikan nilai-nilai karakter. Sejarah adalah fakta kemanusiaan yang harus dijadikan sebagai pembelajaran sekaligus pijakan dalam membangun peradaban selanjutnya, dan puisi merupakan ekspresi dari kebutuhan tertentu setiap manusia. Pikiran mengenai paradigma baru hanya dapat menjadi jelas dan terarah apabila telah diperoleh gagasan yang pasti mengenai paradigma lama yang akan ditinggalkan dan bahkan mungkin dilawan (Faruk, 2015: 105). Dengan kata lain, menyusun gagasan mengenai paradigma baru akan dengan sendirinya menuntut perlunya membangun paradigma lama terlebih dahulu, dan puisi tidak hanya mencerminkan potret masa lalu tetapi juga harapan dimasa depan.

Selama ini pembelajaran apresiasi puisi hanya sebatas pada puisi-puisi dengan tema tertentu dan dari pengarang tertetentu saja. 
Sementara banyak tema-tema puisi yang bervariasi dari berbagai angkatan yang mungkin belum diperkenalkan pada siswa. Memahami makna puisi memang tidak mudah, karena puisi dikemas dalam susun bahasa yang padat dan simbolis. Kehadiran kata-kata dalam puisi diperhitungkan dari berbagai segi, antara lain; makna, kekuatan citraan, rima, dan jangkauan simboliknya (Pradopo, 2014: 123)

Puisi Subagio Sastrowardoyo berjudul Aku Tidak Bisa Menulis Puisi Lagi, termasuk tipografi puisi yang relatif lugas, pilihan kata yang digunakan relatif tidak rumit untuk dipahami namun kaya akan makna. Puisi ini tergolong karya sastra sejarah karena di dalamnya memuat peristiwa sejarah yang kenthal dengan nilai-nilai karakter.

Dari paparan permasalahan di atas maka penelitian tentang puisi Aku Tidak Bisa Menulis Puisi Lagi karya Subagio Sastrowardoyo penting untuk dilakukan. Hal ini bertujuan agar siswa lebih banyak mendapatkan pengalaman batin dan penceraahan jiwa dari berbagai karya cipta puisi yang berbeda, dari latar belakang sosial budaya pengarang yang berbeda, dan dari masa yang berbeda pula. Dari sanalah terhidang nilainilai hakiki kehidupan manusia sebagai pembasuh jiwa. Pendidikan karakter melalui media teks puisi tidak hanya sekadar mewariskan sistem ilmu pengetahuan akan tetapi mewariskan sistem nilai yang mem bentuk kedewasaan. Pendidikan yang tidak hanya sekadar mengasah kemampuan kognitif tetapi juga mengasah kemampuan afektif.

Penelitian serupa pernah dilakukan oleh Yustina Dwinuryati (2017). Fokus penelitian tersebut adalah kajian pendidikan karakter berbasis kearifan lokal pada cerita rakyat. Hasil penelitiannya menyebutkan bahwa terdapat sepuluh nilai pendidikan karakter yang bertumpu pada kearifan lokal dalam cerita rakyat yang relevan digunakan sebagai materi ajar dalam pelaksanaan pembelajaran pendidikan karakter di sekolah. Sementara penelitian ini difokuskan pada muatan nilai karakter dalam teks puisi. Analisis ini dilakukan agar kandungan makna yang sarat dengan muatan nilai-nilai karakter yang bersifat universal dapat dideskripsikan.

\section{METODE PENELITIAN}

Penelitian ini termasuk jenis penelitian kualitatif deskriptif dengan analisis contens. Penelitian kualitatif adalah penelitian yang menghasilkan data deskriptif berupa kata-kata tertulis atau lisan dari orang-orang atau perilaku yang diamati (Moeleong, 2017: 5). Sumber data penelitian berupa dokumen teks puisi yang berjudul Aku Tidak Bisa Menulis Puisi Lagi. Data penelitian ini berupa kata, frase dan kalimat dalam teks puisi Aku Tak Bisa Menulis Puisi Lagi. Pengumpulan data dilakukan dengan cara mengkaji teks, melakukan pencatatan, dan analisis. Teknik analisis data menggunakan teknik simak dan catat. Data yang telah klasifikasi, diinventarisasikan selanjutnya dianalisis maknanya dengan teliti dan analistis. Analisis ini bersifat interaktif yang meliputi empat komponen penelitian yaitu; pengumpulan data, (2) reduksi data, penyajian data, (4) penarikan kesimpulan.

\section{HASIL PENELITIAN DAN PEMBAHASAN}

Puisi sebagai karya seni sastra mampu menampung segala gejolak jiwa manusia. Melalui karya cipta puisi seseorang dapat mengungkapkan ide, pikiran, dan perasaannya dengan media bahasa kepada pembaca. Pesan yang terkandung dalam puisi bukan sekadar curahan perasaan tanpa makna. Warna sebuah puisi sangat ditentukan oleh keadaan latar sosial dan budaya dimana puisi itu terlahir dan diciptakan. Sejarah ditulis karena adanya peristiwa yang terjadi dalam kehidupan manusia.

Peristiwa sejarah tidak terjadi dengan begitu saja, namun sejarah terjadi karena sebab akibat yang ditimbulkan oleh pergolakan dinamika hidup manusia itu sendiri. Kebudayaan suatu masyarakat juga tidak terjadi dengan serta merta, namun kebudayaan tercipta karena proses pemikiran panjang dalam kerangka sebagai pedoman dan sekaligus pandangan dalam bertingkah laku di dalam masayarakat. Demikian halnya dengan sastra, karya sastra hadir karena adanya faktor yang melatarbelakinya sebagai akibat terjadinya sebuah peristiwa. Karya sastra dapat lahir dari situasi bahagia, bencana, musibah, pergolakan politik, bahkan peperangan.

Puisi sebagai simulakra kehidupan manusia tidak lain adalah produk dari kebudayaan bangsa yang harus ditransformasikan dari generasi kegenerasi. Kebudayaan muncul sebagai reaksi atas masifnya berbagai perubahan yang tengah terjadi pada struktur dan kualitas kehidupan sosial (Jenks, 2013: 2). Tema persoalan sosial, 
semangat kebangsaan, cinta tanah air, ketuhanan, dan perdamain banyak diangkat dalam karya cipta puisi dari berbagai angkatan kepenyairan. Puisi dengan judul Aku Tidak Bisa Menulis Puisi Lagi karya Subagio Sastrowardoyo merupakan refleksi realitas sosial pada zamannya yang kaya akan nilai-nilai karakter yang penting untuk dihayati dan diimplentasikan dalam kehidupan bermasyarakat, berbangsa, dan bernegara.

Untuk dapat memahami makna yang terkandung dalam puisi salah satu caranya dengan melalui pendekatan stilistika. Stilistika dapat dipahami sebagai linguistik yang digunakan untuk mengkaji pemakain bahasa dalam karya sastra karena ada keistimewaan di dalamnya. Stilistika (stylistic) adalah ilmu tentang gaya sedangkan stil (style) adalah caracara yang khas bagaimana segala sesuatu diungkapkan dengan cara tertentu sehingga tujuan yang dimaksudkan dapat dicapai dengan maksimal (Ratna, 2016: 3).

Kata kunci untuk stile adalah sebuah pilihan bentuk berbagai aspek kebahasaan. Stile adalah teknik pemilihan ungkapan kebahasan yang dapat mewakili sesuatu yang akan diungkapkan dan sekaligus untuk mencapai efek keindahan. "Style" "stail" atau "gaya" dipandang sebagai cara yang khas dipergunakan oleh seseorang untuk mengutarakan atau mengungkapkan gaya pribadi (Satoto, 2012: 35). Stile ditandai oleh ciri-ciri formal kebahasaan seperti pilihan kata, struktur kalimat, bentukbentuk bahasa figuratif, dan sarana retorika, penggunaan kohesi, dan lain-lain (Abram, 1999: 303). Jadi bagaimana cara seseorang, pembicara, penulis, atau penutur bahasa mempergunakan bahasa adalah stile yang dipilih. Dengan demikian jelaslah bahwa pumpuan kajian stilistika adalah bahasa yang meliputi pilihan kata, gaya bahasa, imagerey dan citraan yang membungkus bentuk puisi itu sendiri untık disibak maknanya. Berikut ini adalah sajian pembahasannya.

\section{AKU TIDAK BISA MENULIS PUISI LAGI}

Aku tidak bisa menulis puisi lagi sejak di Nazi Jerman berjuta Yahudi dilempar ke kamar gas sehingga lemas mati.

Aku tidak bisa menulis puisi lagi sejak di Afrika selatan pejoang-pejoang anti-apartheid disekap berpuluh tahun tanpa diadili.
Aku tidak bisa menulis puisi lagi sejak di Birma para pengunjuk rasa bergelimpangan dibedili tentara secara keji.

Aku tidak bisa menulis puisi lagi Sejak di Jalur Gaza serdadu-serdadu Israel Mematahkan lengan-anak-anak Palistina yang melawan dengan batu

Keindahan punah dari bumi ketika becak-becak dicemplungkan ke laut karena bang becak melanggar peraturan DKI

ketika rakyat berbondong-bondong digusur dari kampung halamannya yang akan disulap jadi real estate dan pusat rekreasi ketika petani dipaksa tanam tebu untuk pabrik-pabrik, sedang hasil padi dan kedelai lebih mendatangkan untung dari rugi

ketika truk-truk di jalan raya dicegat penegak hukum yang langsung meminta pungli ketika keluarga tetangga menangisi kematian anaknya korban tabrak lari.

Aku tidak bisa menulis puisi lagi

sejak keindahan punah di bumi.

\section{Muatan nilai karakter toleransi}

Toleransi adalah sikap dan tindakan yang menghargai perbedaan agama, suku, etnis, pendapat, sikap, dan tindakan orang lain yang berbeda dari dirinya. Dari judul puisi di atas sudah tampak dengan jelas bahwa puisi tersebut menggunakan hasrat yang besar akan penemuan diri, penetapan identitas, eksistensi diri sebagai subjek "Aku". Namun segara pula tampak bahwa "Aku" bukanlah sebagai individu tetapi aku sebagai bagian dari masyarakat dunia. Hal ini dapat dilihat pada pada bait ke-1 sampai dengan bait ke-4 pada puisi tersebut. Kata "Aku" diikuti kemudian frase sejak di Nazi Jerman..., sejak di Afrika Selatan..., sejak di Birma..., sejak di Jalur Gaza..., terjadi peristiwa kemanusiaan. Dari sudut pandang stilistka, pilihan kata "Aku" bukanlah makna denotatif, tetapi bermakna konotatif. Kata "Aku" tidak sekadar menunjuk kata sebut orang pertama tunggal seperti saya, hamba, atau beta. Namun diksi "Aku" dikonotasikan dengan ego, keinginan, perasaan dari setiap jiwa manusia, bukan saja akunya si penyair, namun aku adalah akunya seluruh penduduk dunia. Setiap "Aku" memiliki hak asasasi yang sama, namun setiap kebebasan asasi manusia (aku) selalu di batasi oleh asasi orang atau manuisa lain. Dengan kata lain bebas yang 
tidak sebebas-bebasnya namun kebebasan yang terbatas.

Penggunaan gaya bahasa repetisi sejak di... yang kemudian diikuti keterangan tempat (nama-nama negara) menunjukkan bahwa dimanapun penduduk di dunia ini tidaklah sama, seragam, homogen namun heterogen. Bait pertama pada puisi tersebut mengingatkan kembali peristiwa sejarah pada masa Perang Dunia II. Peristiwa itu dikenal sebagai sebagi tragedi Holocaust yaitu pembunuhan massal yang dilakukan Nazi Jerman di bawah pimpinan Adolf Hitler terhadap berbagai kelompok etnis, keagamaan, bangsa, dan sekuler pada masa PD II.

Bait kedua, menggambarkan peristiwa yang terjadi di Afrika Selatan. Intoleransi terjadi karena satu bangsa namun berbeda ras dan warna kulit. Kulit putih menganggap lebih tinggi daripada bangsanya sendiri yang berkulit hitam. Sementara derajat dan martabat manusia tidak diukur dengan warna kulitnya namun dari perbuatannya. Tuhan menciptakan semua manusia dengan hati dan warna darah yang sama, perbedaan fisik dan warna jasmani adalah bentuk keagungan dan kebesarannya.

Kata "Aku" dalam pandangan Subagio bukanlah aku sebagai superior namun aku juga bukan sebagai subordinasi dari ordinasi. "Aku" bukanlah sebuah kelompok, masyarakat, atau bangsa yang otonom, tetapi "Aku" ada diantara aku yang lain yang memiliki persamaan tujuan namun juga mempunyai perbedaan pandangan. Sepanjang kehidupan "Aku" selalu akan bersinggungan dengan aku yang lain, maka sikap toleransi harus selalu dipupuk dan ditumbuh kembangakan. Pada puisi di atas penyair lebih dominan menggunakan gaya repetisi dalam bentuk kata sejak di, dan dalam bentuk kalimat Aku Tidak Bisa Menulis Puisi Lagi yang selalu diulang-ulang. Perulangan bunyi (i) juga terjadi pada kata mati, diadili, dan keji yang mencitrakan perasaan kepedihan. Larik puisi pada dua bait di atas mengandung pesan bahwa peristiwa itu terjadi dimasa lampau namun terus berulang dan terjadi.

Bait pada puisi ini seolah mengandung pesan kepada pembaca bahwa peristiwa ini masih terjadi dalam bentuk yang serupa. Tawuran antar pelajar yang berbeda sekolah, atau sekadar berbeda jurusan dalam satu sekolah adalah wujud super ego, dimana mereka merasa lebih tinggi atau lebih hebat. Tawuran remaja antar perguruan silat (bela diri) juga wujud intoleransi akan perbedaan identitas. Apabila hal ini terus terjadi maka akan menimbulkan penderitaan banyak pihak, sekolah, orang tua, dan masyarakat yang juga sebagai "Aku". Maka dilukiskan Subagio dalam puisinya Aku Tak Bisa Menulis Puisi Lagi. "Aku” secara konotatif merujuk pada pikiran dan perasaan semua orang, dan "Puisi" adalah ungkapan pikiran dan perasaan itu sendiri, sehingga tak ada lagi katakata untuk diungkapkan karena peristiwa itu terus dan selalu terjadi.

\section{Muatan nilai karakter demokratis}

Demokratis adalah cara berfikir, bersikap, dan bertindak yang menilai sama hak dan kewajiban dirinya dan orang lain. Muatan karakter ini terkandung dalam bait ketiga berikut ini:

Aku tidak bisa menulis puisi lagi sejak di Birma para pengunjuk rasa bergelimpangan dibedili tentara secara keji.

Frase para pengunjuk rasa pada larik puisi tersebut menunjuk pada rakyat Birma. Unjuk rasa terjadi pada umumnya karena rakyat menuntut keadilan akibat kesewenangan penguasa disatu sisi, sementara disisi lain pemerintah membentuk tentara untuk menjaga negara dari kekacauan. Unjuk rasa adalah hak demokrasi yang diatur oleh undang-undang. Setiap negara demokrasi mengatur persamaan hak dan kewajiban warga negaranya. Demikian pula hak untuk berserikat, berkumpul, dan menyampaikan pendapat adalah manifestasi dari demokrasi itu sendiri. Demokrasi diartikan dari rakyat, oleh rakyat, dan untuk rakyat. Namun deikian yang terjadi di Birma, perbedaan pendapat berakhir dengan kesewenangwenangan tentara yang dengan sengaja melakukan tindakan represif. /Para pengunjuk rasa bergelimangan dibedili tentara secara keji/ demikian digambarkan penyair pada baris puisi di atas. Subagio mengemas baris puisi ini begitu estetis dengan pemanfaatan perulangan bunyi konsonan, vokal pada kata para, rasa, tentara, secara yang kemudian dikombinasi dengan kata dibedili dan keji yang mencitrakan perasaan. Orkesta Aku Tidak Bisa Menulis Puisi Lagi, dibedili, keji, menggambarkan citraan perasaan yang menyayat hati.

Muatan nilai karakter demokratis juga tertuang dalam bait keempat, konflik yang terjadi menurut sejarah karena perebutan wilayah, yang masing-masing merasa mempunyai hak atas 
Jalur Gaza. Namun ironisnya, konflik itu telah melanggar batasan kemanusiaan dimana serdadu-serdadu mematahkan lengan anak-anak yang melawan dengan batu. Demikian ironisme yang dikemas penyair dalam puisinya.

Perbedaan pendapat adalah keberagaman pemikiran. Perbedaan pendapat sebuah keniscayaan yang harus dihargai dan dihormati. Di negara kita perbedaan pendapat diatur dalam sistem permusyawaratan dalam hikmat kebijaksanaan untuk mencapai permuwakatan. Abapila permufakatan tidak bisa tercapai maka sistem perwakilan atau voting sebagai piihan terbaik.

\section{Muatan nilai karakter tangung jawab}

Karakter tanggung jawab adalah sikap dan perilaku seseorang untuk melaksanakan tugas dan kewajibannya, yang seharusnya dia lakukan, terhadap diri sendiri, masyarakat, lingkungan (alam, sosial dan budaya), negara dan Tuhan Yang Maha Esa. Muatan nilai karakter pada puisi ini terkandung pada bait kelima,

\section{Keindahan punah dari bumi \\ ketika becak-becak dicemplungkan \\ ke laut karena bang becak melanggar peraturan DKI}

Bait pada puisi ini melukiskan terjadinya permasalahan sosial bangsa kita akibat penguasa pemerintah tidak amanah dengan tanggung jawabnya. Diksi /DKI/ menunjuk ibu kota sebagai pusat pemerintahan, pusat pembuat peraturan, dan pusat kekuasaan. Tanggung jawab negara adalah melindungi warga negaranya untuk mendapatkan pekerjaan dan kehidupan yang layak dalam negerinya sendiri yang merdeka dan berdaulat. Penyair sengaja mengoposisikan kata DKI dengan bang becak, sebagai simbol penguasa dengan rakyat. Dengan alasan ketertiban, pembangunan, dan modernisasi pemerintah telah mengorbankan rakyatnya sendiri dengan cara membuat peraturan yang tidak berpihak kepada kepentingan rakyat kecil.

Liberalisasi dan kapitalisasi telah meruntuhkan sendi-sendi perekonomian rakyat. Dominasi negara terhadap kepentingan asing dari kepentingan rakyatnya sendiri dinarasikan dengan gamblang oleh penyair dalam baris-baris selanjutnya pada bait yang sama. Kata ketika yang selalu diulang-ulang dan diikuti kalimat yang merujuk pada suatu peristiwa yang melemahkan eksistensi rakyat melengkapi keresaahan jiwa penyair.

Ketika rakyat berbondong-bondong, ketika petani dipaksa tanam tebu, ketika truktruk di jalan raya dicegat, ketika keluarga tetangga menangisi kematian...adalah akibat dari rendahnya nilai tanggung jawab pemimpin terhadap rakyatnya.

\section{Muatan nilai karakter peduli sosial dan cintai damai}

Secara keseluruhan puisi Subagio di atas menunjukkan perasaan kepedulian sosial terhadap sesama dengan tanpa membedakan ras, suku, bangsa, dan agama. Keuniversalan pandangan penyair sangat jelas dalam ekspresinya yang dituangkan dalam puisinya. Bait puisi itu ditutup dengan dua baris pada bait terakhir yang sesungguhnya telah diungkapkan sebelumnya, bahkan pada judul puisi tersebut.

Aku tidak bisa menulis puisi lagi sejak keindahan punah dari bumi.

Kata "Aku" bermakna simbolis, aku mewakili harapan dan tujuan hidup semua manusia. Tujuan hidup manusia adalah hidup bahagia. Kebahagian hidup di dunia tidak akan pernah tercapai apabila lingkungan dimana manusia tinggal tidak ada kedamaian, baik karena terjadinya penyimpangan moral, pelanggaran hukum, bencana alam, pencemaran lingkungkan, penggusuran, kriminalitas, peperangan dan sebagainya yang disebabkan oleh perbuatan manusia sendiri atas sikap dan tanggung jawabnya. Sikap dan tanggung jawab inilah sesungguhnya esensi dari karakter manusia.

Kata "keindahan" bereferensi dengan makna kata kedamaian, ketentraman, kesejukan, ketenangan, kenyamanan, ketertiban, kemerdekaan, dan kedaulatan. Ketika manusia telah terampas asasinya sebagai makhluk individu dan makhluk sosial yang bermasyarakat, berbangsa, dan bernegara, maka keindahan hidup itu tak akan pernah terwujud. Sebagaimana pesan Subagio Sastrowardoyo pada puisinya Aku Tidak Bisa Menulis Puisi Lagi.

\section{PENUTUP}

Terdapat lima nilai karakter yang terkandung pada puisi Aku Tidak Bisa Menulis 
Puisi Lagi karya Subagio Sastrowardoyo, yang relevan dijadikan sarana pendidikan generasi muda sebagai katarsis batin (pembasuhan jiwa) bahwa setiap sikap baik ucapan atau perbuatan harus disertai dengan tanggung jawab. Fakta sejarah yang dilukiskan dalam karya sastra (puisi) wajib dijadikan sebagai cermin dan pembelajaran dalam kehidupan bermasyarakat, berbangsa, dan bernegara.

Penelitian ini diharapkan dapat membantu membuka wawasan para pendidik dalam memilah dan memilih materi ajar kesasatraan. Pemanfaatan puisi sebagai media pembelajaran pendidikan karakter juga meupakan upaya melestarikan warisan budaya bangsa dalam bentuk karya sastra. Karya sastra bukan sekadar karya fiktif imajinatif belaka, sastra sejarah memuat peristiwa-peristiwa masa lalu yang nyata terjadi, yang harus dimengerti dan dihayati. Bangsa yang baik adalah bangsa yang tidak akan pernah melupakan sejarah bangsanya dan mengerti sejarah bangsa-bangsa lain di dunia.

\section{DAFTAR PUSTAKA}

Abram, M.H. 2009. A Glossary Terms of Literary Terms. Canada: Wadswort Cangange Learning.

Dwinuryati, Yustina \& Andayani. 2017. "Kajian Pendidikan Karakter Berbasis Kearifan Lokal Pada Cerita Rakyat Nyi Andan Sari dan KI Guru Soka" dalam Jurnal Artefak. Vol.4 (1). 2017.

Endraswara, Suwardi. (2016). Metodologi Penelitian Ekologi Sastra, Konsep, Langkah, dan Penerapan. Jakarta: CAPS.

Faruk. 2015. Metode Penelitian Sastra sebuah Penjelajahan Awal. Yogyakarta: Pustaka Pelajar.

Ilahi, Mohammad Takdir. 2014. Gagalnya Pendidikan Karakter. Yogyakarta: ArRuz Media.

Jenk, Chris. 2013. Culture Studi Kebudayaan.Yogyakarta: Pustaka Pelajar.

Kesuma, dkk. 2012. Pendidikan Karakter Kajian Teori dan Praktik di Sekolah. Bandung: Remaja Rosdakarya.

Koesuma, Doni. 2010. Pendidikan Karakter; Strategi Mendidik Anak di Zaman Global. Jakarta: Grafindo.
Lickona ,Thomas. 2008. Pendidikan Karakter Panduan Mendidik Siswa Menjadi Pintar dan Baik. Bandung: Nusa Media.

Moeleong, Loxy J. 2017. Metodologi Penelitian Kualitatif. Bandung: Remaja Karya.

Pradopo, Rahmat Djoko. 2014. Pengkajian Puisi. Yogyakarta: Gajah Mada University Press.

Ratna, Nyomn Kutha. 2016. Stilistika: Kajian Puitika Bahasa, Sastra, dan Budaya. Yogyakarta: Pustaka Pelajar.

Satoto, Sudiro. 2012. Stilistika. Yogyakarta: Ombak.

Undang-undang RI Nomor 20 Tahun 2003. Tentang: Sistem Pendidikan Nasional.

Wibowo, Agus. 2013. Pendidikan Karakter Berbasis Sastra. Yogyakarta: Pustaka Pelajar.

Zubaidi. 2011. Desain Pendidikan Karakter: Konsep dan Aplikasinya dalam Lembaga Pendidikan. Jakarta: Kencana. 
Jurnal Artefak:

History and Education, Vol.4 No.2 September 2017

Halaman | 160 